\title{
PHYTOPLANKTON VARIABILITY IN THE EASTERN HARBOUR ALEXANDRIA (EGYPT)
}

\author{
Wagdy Labib \\ National Institute of Oceanography and Fisheries, Kayet Bey, \\ Alexandria (Egypt)
}

Key words: Phytoplankton variability, patterns, Alexandria

\begin{abstract}
The present study was conducted during August 1997-August 99 to 1 investigate the Eastern Harbour (eutrophic marine basin) environments and the corresponding phytoplankton community structure, species composition and blooming of different causative organisms that are known to be inherently continuously variable. Anthropogenic eutrophication and geographical dispersion from neighbouring areas into the harbour strongly influenced such variability, and hinder any particular seasonal trends. Yet, the pronounced late winter-spring increasing population and other blooming pulses in summer and autumn caused by less than a dozen species (mainly of diatoms, eutrophication symptom) were predominant characteristics of the production cycle in the harbour. Discharge water into the harbour created rich spectra for algal growth, not necessarily for its nutrient content, but ultimately for the stabilisation of the water column, salinity fluctuation was a crucial factor limiting the phytoplankton variability. Pyramimonas and Micromonas species culminated at maximum abundance in spring with the initiation of thermo-haline stratification of the water column, and it also seems sensitive to the inter-annual variations in temperature. Dinoflagellates predominated at intermittent periods in summer well stabilized the water column, with low nitrate, and relatively high phosphate concentrations. The species-specific patterns include aspects as; the cyclic abundance of the centric diatom Skeletonema costatum; the episodic blooms of indegenous species that normally do not show blooming in the harbour (Cyclotella nana, Leptocylindrus minimus and Lithodesmium undulatum); the reappearance of endogenous dinoflagellate species that were not so far recorded during the last decades (Gymnodinum sanguineum and Gonyaulax spinifera); and the seasonal shift in predominance and
\end{abstract}


trends (increasing-decreasing abundance and disappearance) of the major dinoflagellate species (Prorocentrum triestinum, Gymnodinium catenatum and Scrippsiella trochoidea).

\section{INTRODUCTION}

The habitat-plankton variability occurs as a set of events of different types and impacts subject to short-and-long-term temporal scales, and on-site and far-field spatial effects (Leppänen et al., 1994a).

The relationship between phytoplankton variability and ambient environmental condition has different enigmatic aspects. The external physical and chemical forcing processes are crucial factors in controlling phytoplankton primary production, and determining the structure of the pelagic foodweb in an area (Colijn, 1998). Recent conceptual models of the trophodynamic functioning of planktonic. ecosystem (Mann and Lazier. 1991) proposed that the external forces act upon the biological system in a series of bifurcation; by setting the conditions leading to the dominance of a given phytoplankton assemblage and by controlling the processes involved.

The Eastern Harbour of Alexandria is located in the central part of the city. It is a relatively shallow, semi-enclosed marine basin, and sheltered from the open sea by a breakwater of two inlets. The harbour has an area of about $2.53 \mathrm{Km}^{2}$, average depth of about $5 \mathrm{~m}$, and a water volume of about $15.2 \times 10^{6} \mathrm{~m}^{3}$. Since 1977 , the diversion of municipal wastewater into the harbour rendered its water eutrophic (Halim et al., 1980). Meanwhile, the harbour due to water circulation is subjected to additional amount of municipal wastewater from the main sewer of Alexandria (kayet Bey), located at its western vicinity, as well as from Mex Bay in the west. The harbour is a site of numerous ecological phytoplankton studies, the details are included in reports of Dowidar (1965), El-Maghraby and Halim (1965), Sultan (1975), Halim et al. (1980), Zaghloul (1988), Zaghloul \& Halim (1992), Hussein (1994), Labib (1994 a,b; 2000 a,b). Zaghloul (1995) offered a comparative study of the phytoplankton standing crop and composition and concluded that the progressive eutrophication caused by the continuous discharge of untreated domestic sewage has strong impact on the development of heavy phytoplankton blooms. The author also confirmed the results of the previous studies declaring 
water stability a major contributory regulating the abundance of phytoplankton .

The present contribution seeks to put into perspective some features of the patterns of the phytoplankton variability relevant to some habitat variables. Unfortunately, previous quantitative surveys in the harbour sample the phytoplankton neither adequately (monthly), nor make the type of some concurrent measurements of biological processes and physical and chemical habitat variables needed to quantify this variability. As a result, quantification of the causes of variability is limited and many principals of the patterns of the phytoplankton variability have yet to be elucidated.

\section{MATERIALS AND METHODS}

Field-oriented research, including phytoplankton abundance and composition and environmental factors measurements was carried out at a fixed station ( $4 \mathrm{~m}$ depth) in the Eastern Harbour of Alexandria (Egypt) from August 1997 to August 99.

The physico-chemical measurements include the surface and the above bottom temperature (by a thermometer accuratc to $\pm 0.1^{\circ} \mathrm{C}$ ) and salinity (salinity refracto-meter), as well as the surface concentrations of the dissolved inorganic nitrate, phosphate and reactive silicate (Strickland and Parsons, 1972).

The phytoplankton samples were first examined for identification of flagellates, then preserved adding neutral formalin (4\%) and a few drops of Lugol's acid solution, and counted (Utermöhl, 1958). The nomenclature followed mainly the checklists of Edmondson (1959), Hendey (1964), Park and Dixon (1976), Dodge (1982), and Sournia (1986).

Statistical analysis was done by applying the multiple linear regression model (Hintze, 1993) that computed to determine the relative importance of environmental parameters including ; temperature, salinity, nitrate, silicate, phosphate (independent variables), and the corresponded phytoplankton standing crop and community structure (dependent variables). This model is helpful predicting type of multiple influence, and correlation, and it explains the extent of the effect of environmental parameters on the phytoplankton variability.

The model reads: 
$\mathrm{Y}=$ Intercept $\pm \mathrm{R}_{1} * \mathrm{X}_{1} \pm \mathrm{R}_{2} * \mathrm{X}_{2} \pm$
$\mathrm{R}_{3} * \mathrm{X}_{3} \ldots \ldots \ldots \ldots\left(\mathrm{R}^{2}=\ldots.\right)$

Where $Y$ : dependent variable; $X_{1}, X_{2} \ldots$ independent variable; $R_{3}$, $R_{2} \ldots$; correlation coefficient, $R^{2}$ : multiple correlation. The significant level at $0.05, p$ test.

\section{RESULTS AND DISCUSSION}

\section{Phytoplankton variability}

The changes observed in the community structure, species composition and the occurrence of several phytoplankton peaks with different causative organisms, certainly indicate the arrival of water masses from the adjacent Mediterranean areas with different properties into the harbour. Advected waters bring immigrated species into the harbour that may prevail in the developing annual succession. As a result, dominant species in one year may completely disappear in the next. The progressive eutrophication seems also hindering any particular seasonal trends, similar to the finding of Fonda Umani et al. (1995). Phytoplankton in the harbour reveals such changes since 77-78 (Halim et al., 1980).

The phytoplankton community structure, the dominant species recorded during the investigated period and ambient physical and chemical measurements are shown in Figure 1, and Table 1.

The standing crop gained an average of $2.19 \times 10^{6}$ cell $1^{-1}$ in $97-98$, almost equal to that recorded for the next year $\left(2.5 \times 10^{6}\right.$ cell $\left.\mathrm{l}^{-1}\right)$. Diatoms represented the major fraction ( 72.82 and $76 \%$ of the total standing crop, respectively), followed by dinoflagellates (14.9 and $11.25 \%)$, microflagellates (7.9 and $8.82 \%$ ), and euglenophytes ( 3 and $1.42 \%$ ). The present diatom contribution is the higher reported in the harbour during the last decade; $(66.04,59.3$, and $24 \%$ during 86-87, 90-91, and 91-92, respectively) while dinoflagellates sustained a lower contribution (Zaghloul and Halim, 1992; Hussein, 1994; Zaghloul, 1995).

Diatom species, perennial forms produced vast successive blooming pulses most of the time, representing the sole constituent of the community during late autumn-winter-early spring periods. The species composition and predominance were completely different from year to year. Lithodesmium undulatum dominated in November 97, followed by Skeletonema costatum. However, during NovemberDecember 98, the dominance was mainly attributed to the 
proliferation of Cyclotella nana, shared by Asterionella glacialis. Diatom species culminated at $9.63 \times 10^{6}$ cell $l^{-1}$ and $10.19 \times 10^{6}$ cell $l^{-1}$ on 3 April and 8 June 99, respectively, due to the blooming of $S$. costatum. Other dominant diatom species are shown in Figure 1.

Dinoflagellates were leading in summer and fall (97-98). However, their high levels of abundance were not maintained during the summer. Their occurrence reflected annual differences: Prorocentrum triestimum formed two distinct peaks on 30 September 97, and on 18 July 98; Prorocentrum minimum was also important $\left(0.82 \times 10^{6}\right.$ cell $\left.1^{-1}\right)$, and Scrippsiella trochoidea formed its massive bloom in late August-early September, 98 . Yet, these species were of insignificant contribution in 1999, and instead diatoms became the causative bloom species. Dinoflagellates sporadically appeared with a well developed thermo-haline stratified water column and at different nutrient levels, in accordance with the other previous reports in the harbour (Labib, 94 b, 96, 98, 2000; Labib and Halim 1995), and elsewhere (Anderson, 1997).

Microflagellates (Pyramimonas and Micromonas species) shared the predominance in active role at intermittent periods during spring and summer-early autumn. They were responsible for the dense blooms, all over the period in mid-April 98 and early May 99. These blooms will be discussed later. Other minor blooms were also recorded $\left(1.32 \times 10^{6}-6.93 \times 10^{6}\right.$ cell $1^{-1}$, the latter on 26 October 98$)$. Microflagellates, exhibiting a similar behaviour to dinoflagellates appear to be most sensitive to growth inhibition by small-scale turbulence, in agreement with Thomas and Gibson (1990).

\section{Variability in the dynamics of late winter-early spring increasing population}

A main feature of the annual phytoplankton cycle is the occurrence of distinct increasing phytoplankton density during late winter-early spring, which represents a classical paradigm cycle, in which the population awaits partial stratification to flourish. It is the time of the transition from the winter, isothermal-isohaline water column, to summer (stratified) situation. Since a rise in surface temperature by $1.4-2^{\circ} \mathrm{C}$ was observed during the last two weeks of March 98, and February 99 , such plankton cycle attribute seems sensitive to the inter-annual variations in temperature, which probably could be considered a sharing regulating factor. According to Hitchcock and Smayda (1977) temperature, an allogenic factor is considered as a 
primary bloom trigger, or with the annual diatom maxima (Smayda, 1980), and it influences succession patterns (Karentz and Smayda, 1984). The community in late winter-early spring was dominated by opportunistic, fast-growing diatoms like $S$. costatum, and A. glacialis. These species seem to respond quickly to new nutrients induced, which has been proved by enrichment experiments (Malej et al., 1998).

The standing crop increased significantly to $0.64 \times 10^{6}$ cell $\mathrm{l}^{-1}$ on 30 March $98, S$. costatum contributed $0.54 \times 10^{6}$ cell $1^{-1}, 84.37 \%$. The ambient physical variables showed surface temperature at $18.6^{\circ} \mathrm{C}$, salinity $38 \mathrm{ppt}$, and a weakly, positively stratified water column within $0.4^{\circ} \mathrm{C}$ and $0.2 \mathrm{ppt}$ between the warmer, less saline surface and that over the bottom. Other minor species were Euglena spp. $(10.23 \%)$, Chaetoceros affinis, Lithodesmium undulatum, Coscinodiscus oculus irridus, Thalassiosira sp., and P. triestinum. This pronounced phytoplankton increase extended till 5 May, with two major peaks on 13 April (microflagellate bloom) and on 5 May $\left(1.1 \times 10^{6}\right.$ cell $^{-1}$, S. costatum, $\left.93.69 \%\right)$.

The time of inception and magnitude of such increased standing crop varied in 1999. It began one month earlier, 27 February; temperature was lower $\left(14.6^{\circ} \mathrm{C}\right)$, salinity was slightly higher $(38.8$ ppt), and at intermediate nutrient levels $\left(1.8 \mu \mathrm{M} \mathrm{NO} 3,1.8 \mu \mathrm{M} \mathrm{SiO}_{4}\right.$ and $2 \mu \mathrm{M} \quad \mathrm{PO}_{4}$ ), but it was proceeded by enhanced nutrient concentrations between 11-22 February. The standing crop gained $0.8 \times 10^{6}$ cell $\mathrm{r}^{-1}$. Again, $S$. costatum was the responsible species $\left(0.6 \times 10^{6}\right.$ cell $\left.\mathrm{I}^{-1}, 69.62 \%\right)$, followed in abundance by $A$. glacialis $(21.52 \%)$, and it dominated till 4 May $\left(0.59 \times 10^{6}\right.$ cell $\left.\mathrm{l}^{-1}\right)$, representing an important constituent of the community in summer.

\section{Variability of recurrent occurrence of the maximal spring bloom}

The present study refutes the recurrent occurrence of the maximal phytoplankton bloom in spring. Microflagellate species were the causative species, but nor is the timing, accompanied habitat conditions and the magnitude is fixed. The first bloom took place on 13 April 98, Pyramimonas species contributed $16.5 \times 10^{6}$ cell $\mathrm{l}^{-1}$ at $18.8^{\circ} \mathrm{C}, 38 \mathrm{ppt}$ and a weak themo-haline stratified water column with $0.8^{\circ} \mathrm{C}$ and $0.8 \mathrm{ppt}$ between the warmer, less saline surface water and that above the bottom. Again, in early May 99, microflagellates (mainly Micromonas species) overwhelmingly dominated, culminating at a population size of $21 \times 10^{6} \mathrm{cell}^{-1}$, the peak shifted 


\section{PHYTOPLANKTON VARLABILITY IN THE EASTERN HARBOUR ALEXANDRIA (EGYPT)}

about 3 weeks. The bloom occurred at relatively high surface temperature $\left(19.3^{\circ} \mathrm{C}\right)$, unchanged salinity, a partially stratified water column, within $0.3^{\circ} \mathrm{C}$ and $1 \mathrm{ppt}$, exhausted nitrate $(0.5 \mu \mathrm{M})$, intermediate silicate $(1.8 \mu \mathrm{M})$, and relatively high phosphate concentrations $(3 \mu \mathrm{M})$. Again, temperature acting seems to have been implicated as a bloom trigger, a rise by $1.6-1.8^{\circ} \mathrm{C}$ was measured prior to the blooms. Microflagellate species have been previously reported in the harbour forming its major peak on 11 May $91\left(28.3 \times 10^{6}\right.$ cell $1^{-1}$, Labib, 1994b), with $21.5^{\circ} \mathrm{C}$ and 37.3 ppt. An abrupt phytoplankton increase in spring and autumn was reported by Falkowski and Raven (1997), and the predominance of microflagellates (Maita and Odate 1998), in temperate waters.

Since Steuer (1935), the spring bloom, as a temporal variability can be addressed at decadal level in Alexandria waters, the seasonal cycle was bimodal (spring and autumn bloom). The situation changed in 1977, and instead of the bimodal cycle, successive blooming pulses occurred in summer and fall, with no particular seasonal trend. Yet, the spring bloom persisted as a permanent feature. According to Sournia et al. (1987) \& Cloern and Jassby (1995), the spring bloom is the most characteristic event in the annual phytoplankton cycle in temperate bays and estuaries.

\section{Species-specific patterns}

There are considerable variations in bloom dynamics and occurrence patterns of individual species. Explanation for the present increased frequency of diatom blooms and the shifts in the species composition in the harbour could be attributed as previously mentioned to man-made over fertilization of the seawater by nutrients, through discharge water input (anthropogenic eutrophication), which could help creating rich spectra for algal growth, and the occurrence of recurrent blooms; and to the geographical dispersion from neighbouring areas by transport processes. According to Smayda (1980, 1983); Cloern and Nichols (1985); Sournia et al. (1987) temperate bays and estuarines are characterized by such pronounced variability, where phytoplankton is highly dynamic and recurrent seasonal blooms are well documented. Water stabilisation by discharge water is an essential factor that determines not only the magnitude of phytoplankton production, but ultimately leads to community change or species succession (Estrada 
et al., 1988). Alvarez Cobelas et al. (1994), and Dokulil and Padisak, (1994) reported shifts in species composition related to eutrophication. Several species-specific patterns could be detected:

1- Episodic bloom occurrence of indegenous species that normally do not bloom, or show modest seasonal increase are common. These species and their succession are as follows: Lithodesmium undulatum

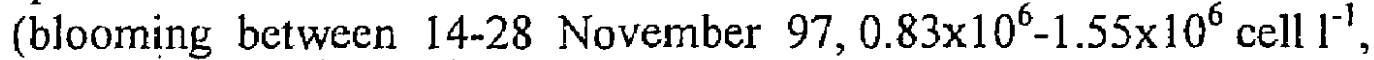
and at $0.63 \times 10^{6}$ cell $^{-1}$, on 21 September 98); Rhizosolenia delicatula (4 March $98,3 \times 10^{6}$ cell $1^{-1}$, and at $0.68 \times 10^{6}$ cell $1^{-1}, 76.4 \%$ on 7 July 99); Cyclotella nana (very common in summer-early winter, with two

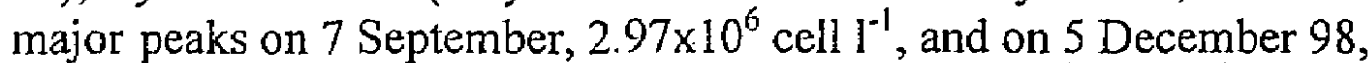
$1.3 \times 10^{6}$ cell $\left.1^{-1}\right)$; Leptocylendrus mimimum $\left(1.5 \times 10^{6}\right.$ cell $1^{-1}$ on 14 September 98, then it was rarely observed); Asterionella glacialis

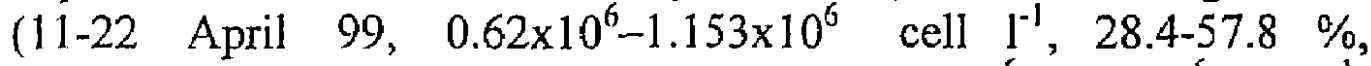
respectively); and Nitzschia longissima $\left(0.26 \times 10^{6}-0.28 \times 10^{6}\right.$ cell $1^{-1}$; forming mono-species bloom in August 99, $1.9 \times 10^{6}-3.67 \times 10^{6}$ cell $^{-1}$ ).

2- Seasonal shifts in predominance of the major dinoflagellate species: Prorocentrum triestinum (of common occurrence, at $3.6 \times 10^{6}$ cell $\mathrm{I}^{-1}$ on 30 September 97 , a major bloom on 18 July $98,7.53 \times 10^{6}$ cell $\mathrm{I}^{-1}$, and it had a very low contribution in 99); Gymnodinum catenatum (very low numbers in 97 and 99 , main occurrence in July 98, with $0.32 \times 10^{6}$ cell $1^{-1}$ on $18 \mathrm{July}$ ); Prorocentrum minimum (common occurrence all over the period, at $0.82 \times 10^{6}$ cell $1^{-1}$ on 18 July 98 , and less so on 16 June $99,0.39 \times 10^{6}$ cell $1^{-1}$ ); and Scrippsiella trochoidea (low contribution in 97 and 99, but sharing the red tide bloom period between 29 August -1 September 98 with $1.53 \times 10^{6}$ $1.67 \times 10^{5}$ cell $1^{-1}$ ). These species are well known in the harbour. $P$. triestinum has often formed blooms in the harbour from late spring to early autumn (Labib, 1994 a,b), giving abnormal heavy bloom in April $92\left(75 \times 10^{6}\right.$ cell. $1^{-1}$, Zaghloul, 1995). The species caused water discoloration between 3-11 April 1993, with a population peak of $71 \times 10^{6}$ (Labib, 1996). It is a well known red tide form in Mex Bay (Mikhail, 97; Labib, 2000a), particularly found in semi-enclosed areas subjected to land drainage, where the supply of $\mathrm{NH}_{4}$ and $\mathrm{NO}_{3}$ is plentiful (Iizuka, 1976). G. catenatum first found by the author in the Mediterranean neritic waters of Alexandria during 1992. It was not observed in the harbour during March and April, started to be rarely occurred by May, attaining its highest density of $0.98 \times 10^{6} \mathrm{cell}^{-1}, 71.5$ $\%$ during July 96 . The species, during the same month contributed 


\section{PHYTOPLANKTON VARIABILITY IN THE EASTERN HARBOUR ALEXANDRIA (EGYPT)}

$0.75 \times 10^{6}$ cell. $1^{-1}$ in Abu Qir Bay, east of Alexandria, at $28.8^{\circ} \mathrm{C}, 37.5$ ppt and high nitrate, $6.4 \mu \mathrm{M}$., (Labib, 1998). In Mex Bay, its massive occurrence occurred in October $93\left(1.7 \times 10^{6}\right.$ cell $\left.\mathrm{l}^{-1}, 76.5 \%\right)$, and September 96, $1.8 \times 10^{6}$ cell. $l^{-1}$ (Labib, 2000a). Apparently no cases of toxicity have accompanied its blooms in Alexandria waters, probably due to its low number. The first reported outbreaks of paralytic shellfish poisoning attributed to the unarmoured, chainforming G. catenatum occurred in 1976 (Estrada et al., 1984). S. trochoidea was previously reported a common species in the harbour, attaining its main occurrence in late spring (Labib, 1994b), with combination of high nutrient concentrations and a density stratificd water column. This species achieved its peak in Mex Bay on 23-24 June $97\left(4.1 \times 10^{6}-4.5 \times 10^{6}\right.$ cell $\mathrm{I}^{-1}$, respectively, raising chlorophy!l $a$ to $18.5 \mu \mathrm{g} \mathrm{^{-1 }}$ (labib, 2000a). It is a well-known red tide form (Park, 1991), and no symptoms of toxicity accompanied its bloom, here and/or elsewhere (Koray, 1992). However, wild and cultured fish kills have been associated with its blooms through the generation of anoxic conditions (Hallegraeff, 1992), though it induced no mortality of Artemia larvae at any time (Demaret et al., 1995).

3- Reappearance of endogenous dinoflagellate species that seem not to be recorded during the last decades; Gymnodinum sanguineum (September-early October), Gonyaulax spinifera (mid-October-late December), and Dinophysis acuminata (late April). There is a steady increase in the numbers of $G$. sanguineum, which could help formation of a new red tide bloom occurrence in the harbour in near future.

4- Species exhibit cycles in bloom abundance, the centric diatom $S$. costatum represents a good example. Its occurrence was previously discussed. The species is considered to be quantitatively the most contributory species in the harbour since 1956-57 (El-Maghraby and Halim, 1965). Dowidar (1965) reported its 4 peaks in May, July, September and October (average $4.6 \times 10^{6} \mathrm{cell}^{-1}$ ). It was dominated in $72-73$ with increased numbers from March, and at $12.2 \times 10^{6} \mathrm{cell}^{-1}$ in May 73 (Sultan, 1975), and in 77-78 (Halim et al., 1980). Recent observations revealed the pre-dominance of $S$. costatum from February to July, with $1.3 \times 10^{6}-8.53 \times 10^{6}$ cell $1^{-1}$ (Zaghloul and Halim, 1992; Hussein, 1994; Labib, 1994a, 2000a,b; Zaghloul, 1995). It is a 
cosmopolitan, well known red tide species (Mingazzini et al., 1992), reported as an indicator of eutrophication (Mihnea, 1985).

5- Variability as "event". A given "event" may be a single, isolated occurrence and therefore rare and even unique. Comparing with the previous data during the last 41-year time series, the novel 87 and 91 beneficial "olive tide" of Amphicrysis compressa is a well representative. The species was first reported in 87 , with its intensive occurrence in May, $3.5 \times 10^{6}$ cell $1^{-1}$, and it was considered a biological index of wastewater discharged into the harbour (Zaghloul \& Halim, 1992). Its red tide bloom was followed in June 91, when it caused water discoloration, culminating at $>53 \times 10^{6}$ cell $1^{-1}$ on 19 June, raising chlorophyll $a$ content to $50 \mu \mathrm{g} \mathrm{l}^{-1}$ (Labib, 1992). This bloom lasted for a week, and spread over a vast area for about $28 \mathrm{Km}$ along Alexandria coast. A bloom of $A$. compressa never having been recorded in the harbour before 87 , nor since.

6- Increased number of the species that are considered as eutrophication indices, including: the freshwater forms, Melosira spp. (M. crucipanctata, M. granulata, mostly in May); Rhizosolenia spccies ( $R$. delicatula, $R$. fragilissima, $R$. hebetata, and $R$. setigera); and Euglena spp. (E. acus, E. granulata, E. spirulina, and Eutreptiella spp., mostly in September and October), Phacus triqueter (August-October, with $0.063 \times 10^{6}$ cell $1^{-1}$ in late November 99), beside the forming diatom bloom species previously mentioned.

7- Decreasing abundance/disappearance of species that were previously recorded dominant or forming red tide occurrence in the harbour. Among them are: the dinoflagellates, Alexandrium minutum (a very rare occurrence, mostly in April-May, 0.002-0.004 x $10^{6}$ cell $\mathrm{I}^{-1}$ ); the diatoms, Ceratulina pelagica and Nitzschia frigida (not observed, at $0.77 \times 10^{6}$ cell $1^{-1}$ on 4 June, and $0.83 \times 10^{6}$ cell $1^{-1}, 8$ June 91 , respectively, labib 1994b), Chaetoceros affinis (mostly in February-March and May, up to $5 \times 10^{6}$ cell $1^{-1}$ in July 88), and Cyclotella meneghiniana (mostly in summer, at $2.8 \times 10^{6}-3.5 \times 10^{6}$ cell $1^{-1}$, in July 88, Zaghloul and Halim, 1992); and the cyanobacterium, Anabaena sp. (not observed, at $13.7 \times 10^{6}$ unit $\mathrm{I}^{-1}$, September 91, Hussein 1994). Alexandrium minutum is of a regular occurrence in the harbour since 1958, when it was first reported as new genus, new species, with $>25 \times 10^{6}$ cell $1^{-1}$ (Halim, 1960 a). The species contributed several peaks during the last 3 decades; in July 
$73,1.87 \times 10^{6}$ cell $^{-1}$ (Sultan, 1975); May-June 87, $6 \times 10^{6}-10 \times 10^{6}$ cell $\Gamma^{-}$ 1 (Zaghloul and Hahim, 1992); and in July-August $91,1.7 \times 10^{6}$ $2.1 \times 10^{6}$ cell $1^{-1}$ (Labib, 1994b). Its massive red tide bloom atong Alexandria coast triggered in October 94 , with a peak of $24.4 \times 10^{6}$ cell $1^{-1}$, causing fish and invertebrate mortality, with evidences of toxicity (Labib and Halim, 1995).

\section{Multiple Linear regression}

The Eastern Harbour environments inherently are continuously variable; all physical, chemical and features of the phytoplankton are affected. The statistical model reads:

The standing crop $=23.49-0.041 *$ Temperature $-0.556 *$ Salinity $\mathrm{p}<0.05$.

$$
-0.949 * \mathrm{NO}_{3}-0.829 * \mathrm{SiO}_{4}+1.897 * \mathrm{PO}_{4}, \mathrm{R}^{2}=0.21 \text {, }
$$

The model predicts inverse relation of the measured parametcrs, except for phosphate, with the standing crop. The highest correlation coefficient of phosphate signals its significant contribution. However, the model explains only $21 \%$ of the phytoplankton variability, other unknown factors are certainly implicated affecting phytoplankton variability.

The physical parameters represented by temperature and salinity are fundamental. The model reads:

The standing crop $=43.27-0.13 *$ Temperature $-1.01 *$ Salinity, $R^{2}=0.099$, ( $p>0.05$ ), controlling in combination about $10 \%$ of the standing crop variability. Salinity for its highest correlation coefficient seems a significant contributory (Figure 2).

As given in Table (1), distinct seasonal temperature variations, with several regular trends could be observed. Yet, time shift occurred between the two year-time series. Surface water temperature oscillated normally between minimum of $12-12.4^{\circ} \mathrm{C}$ in the middle of both February 98 and January 99, respectively, to its maximum usually occurs in August $\left(29.5^{\circ} \mathrm{C}\right.$, on 10 August 98 ). Two thermal regimes can be observed, the first is lasting from March (represents the start of surface heating) to late September when the surface water is normally warmer than that above the bottom, the highest difference between the surface and over-bottom temperature reached $3^{\circ} \mathrm{C}$ in August 98. The second extended from early October to February with inverse thermal stratification (November-December, surface temperature shows a tendency to a decrease within $5-6^{\circ} \mathrm{C}$ ), and a homothermal condition mostly in January and February. The 
correlation matrix of physico-chemical measurements and phytoplankton is given in Table 2. Temperature was positively, insignificant correlated with the standing crop, probably due to its wide range $(r=0.17, p>0.05)$. It is difficult to define a certain limited temperature range when the phytoplankton bloomed within. Even in winter (late January-early February 99), a pronounced phytoplankton increase was detected at $12.4-13^{\circ} \mathrm{C}$. However, statistically when temperature range is treated as three levels; temperature $>25^{\circ} \mathrm{C}$, between $20-25^{\circ} \mathrm{C}$ and $<20^{\circ} \mathrm{C}$, a significant, inverse correlation was found at the first and the third levels $(r=-0.51$ for both, $p<0.05)$, while the standing crop is positively, insignificantly correlated with the $20-25^{\circ} \mathrm{C}(r=0.1, p>0.05)$. Temperature seems affecting also the variability of the main phytoplankton groups, particularly dinoflagellates $(r=0.41, p<0.05)$; diatoms and euglenophytes seem to be less affected. Microflagellates for its infrequent occurrence, culminating episode peaks at different intermittent periods show a very weak inverse and insignificant correlation with temperature. It is well documented that variation in the annual temperature regime is a major cause of temporal phytoplankton variability in temperate bays (Gayoso, 1998). How temperature affects the phytoplankton succession and species composition is complex answer.

The inter-annual variability of the surface salinity within the two years was fairly large (Table I). Salinity can be as high as $39.5 \mathrm{ppt}$, but values between 35 and $38 \mathrm{ppt}$ were common, and much lower values were also temporarily recorded. Such values suggest lateral advection of marine water from the open sea and aiso reflect a direct impact of discharge water input into the harbour. Despite the large fluctuations occurred, prominently regular and recurrent trends are detected; salinity <37.5 ppt in summer-mid-autumn; and values $>39^{\circ}$ ppt from early winter (December) to spring (mid-March to late April). Surface salinity, influenced by the partial reduction of municipal wastewater directly discharged to the harbour, is the highest (mean 38 ppt) during the last two decades, which was estimated as 35.8-37.4 ppt (El- Nady, 1981; Shriadah, 82; Aboul-Kassim, 87; Zaghloul, 88, and Labib, 2000b). Salinity over the bottom was always high, with 37-39.9 ppt. Yet, values < $37 \mathrm{ppt}$ were also occasionally measured, particularly in summer and autumn. The salinity profile indicated distinct patterns; a weak halo-stratification to be existed by May, and it was followed by a well-developed vertical gradient from August to October; and a homohaline condition till spring associated with noticeable rise in salinity. Salinity seems to represent the most crucial 
factor controlling the standing crop variability, with a significant inverse correlation $(\mathrm{r}=-0.29, \mathrm{p}<0.05)$. Salinity seems influencing also the community structure, exhibiting negative correlation with the variability of the most phytoplankton groups. It is significant with diatoms and dinoflagellates $(r=-0.42$ and 0.45 , respectively, $p<$ 0.05 ). The field observations correspond well with the statistical results, the massive phytoplankton occurrence in summer and fall (till mid-November), took place at salinity range $33-38.5 \mathrm{ppt}$. According to Smayda (1980), salinity has bearing on the temporal development and spatial distribution of the phytoplankton standing crop, blooming and species succession.

Nutrient concentration's variability, driven by external and in situ processes, is prominent environmental characteristics in the harbour. Sources leading to their distinct variability include water exchange, seasonal mixing, discharge water input and exhaustion by phytoplankton uptake. Thus, nutrient seem unlimiting growth factor. Despite the large inter-annual nutrient variability (Table 1), some common trends are distinguished; such as building-up of high concentrations in winter (December-February), with limited phytoplankton growth; also high concentrations in early spring (late March-early April), which probably attribute to leaching from agricultural activities occur primarily in spring; sharp diminution in summer and autumn accompanying intensive phytoplankton occurrence; variable nutrient concentrations with the phytoplankton bloom pulses, not necessarily mean to be low; and the nutrients input do not balance the uptake during the heavy phytoplankton blooms. Surface nitrate fluctuated between 0.35 and $4.5 \mu \mathrm{M}$, silicate $0.6-5.2$ $\mu \mathrm{M}$ and phosphate $0.5-4.2 \mu \mathrm{M}$. The very low concentrations with the phytoplankton blooms in summer suggest nitrate and silicate phytoplankton growth (magnitude) controlling factors during this period. Their new supply and replenishment accelerate the existence of new production, particularly with the diatom blooms in JulyAugust 99, in accordance with other results (Barber and Smith, 1981). The correlation matrix indicates negative correlation of salinity with all the nutrients measured, reflecting the water discharge to be their main source. Meanwhile, their variability is significantly positively inter-correlated with each other. Expected negative, insignificant relationship is found between nitrate, silicate and the standing crop, $(r=-0.18 \&-0.16, p>0.05$; Figure 3 ), while it is positive with 
phosphate. Relatively high phosphate concentrations $(2.3-4 \mu \mathrm{M})$ accompanied the intensive occurrence of the dinoflagellates and microflagellates at intermittent periods. Moreover, the major diatom blooms resulted, generally in reduced phosphate concentrations. According to Pybus (1980) dinoflagellates during their bloom peaks can produce extracellular organic phosphorus and its conversion into inorganic phosphate as these blooms declined. Smayda (1983) added that mixing and recycled processes (other sources of variability), introduce phosphate in estuaries. The previous field data in the harbour suggested specific relation between the high phosphate concentrations and blooming of the dinoflagellate species; Alexandrium minutum, $6 \times 10^{6}-10 \times 10^{6}$ cell $\mathrm{I}^{-1}$, with $4.9-5.3 \mu \mathrm{M} \mathrm{PO}_{4}$, May 1987 (Zaghloul and Halim, 1992); Prorocentrum triestinum, $75 \times 10^{6}$ cell ${ }^{-1}, 8.4 \mu \mathrm{M}$, April 92 (Zaghloul, 95); and at $71 \times 10^{6}$ cell ${ }^{-1}$, April 93, $3.8 \mu \mathrm{M}$ (Labib, 96), as well as Scrippsiella trochoidea, $5.64 \times 10^{6}$ cell $1^{-1}, 3.15 \mu \mathrm{M}$ (Labib, 2000). Prorocentrum cordatum and $P$. micans dominated in the Western Harbour of Alexandria during February 1989 with $5.7 \mu \mathrm{M}$ (Zaghloul, 1992). In Mex Bay, Prorocentrum triestinum reached its peak of $11.6 \times 10^{6}$ cell $1^{-1}$ during August 97 with $6.5 \mu \mathrm{M} \mathrm{PO}$, (Labib, 2000a). Temperature and phosphate seem to affect the occurrence of Gymnodinium catenatum, its bloom in Alexandria neritic waters during July and October maintained 3.8-5.9 $\mu \mathrm{M} \mathrm{PO}_{4}$ (Labib, 1998, 2000). Protoperidinium pouchetii bloomed in the Adriatic with high phosphate level (Riegman el al., 1992). According to Smayda (1990) and Riegman and Kuipers (1994) elevated nutrient levels and/or altered nutrient ratios, during a period of progressive increase cause differential and variable sclection of bloom species. Nitrate shows also insignificant, positive correlation with dinoflagellates, but it is inversely related to other groups. Silicate was negatively, insignificantly correlated with all groups, but higher with diatoms $(r=-0.13, p>0.05)$.

Despite the present expected and/or unexpected relationship between the standing crop (dependent variable) and the measured physico-chemical parameters (independent variables), to define and quantify factor/s controlling phytoplankton variability, these parameters seem insufficient to explain mechanisms of the phytoplankton dynamic responses. Reasons could include factors as the great habitat-phytoplankton variability ; rapid change of the phytoplankton community structure in the harbour, which has been documented to vary considerably within a few days, and a dense 
bloom is replaced immediately after its dissipation by another one (Labib, 1994a,b); and the sampling time protocol. Meanwhile, the nutrient-phytoplankton relationship is under multi-factorial control. According to Lindeboom et al. (1995), the extent to which the statistically derived interference of ecological consequences actually contributes to the observed variability in plankton behaviour is often unresolved. However, the chemical variables measured have importance in the extent of eutrophication in Alexandria waters.

\section{In conclusion:}

The present contribution, in a highly dynamic marine basin, sceks to put into perspective some features of the patterns of the phytoplankton variability relevant to some physical and chemical issues induced mainly by anthropogenic modification and the arrival of different water masses. The water discharge into the harbour accelerated the phytoplankton growth for its nutrients content, their fast replenishment and the potential role stabilizing the water column, salinity was proved an essential factor controlling the phytoplankton variability. Persistent variations, in the phytoplankton community structure, successions and blooms resulted from the variable interplay among the continuous variability of the physical and chemical habitat properties. Diatoms prevailed most of the time during mixing and/or stable water condition, and with different nutrient concentrations. Microflagellates dominated in spring, while dinoflagellates at intermittent periods in summer stabilized water. High phosphate accompanied its massive occurrence. The dramatic change in the species composition and abundance in which a dominant species in one year may completely disappear in the next is mainly attributed to advected waters which bring immigrated species into the harbour that may prevail in the developing annual succession. Despite the high degree of variability in habitat, there are some impressive phytoplankton features in the seasonal cycle, occurrence of recurrent blooms and species predominance. The marked spring increasing population and other bloom pulses in summer and fall, caused by less than a dozen species (eutrophication symptoms) are predominant characteristics of the production cycle in the Eastern Harbour and probably in the neritic waters of Alexandria. The spring bloom triggered with a pronounced rise in temperature and the initiation of density stratified water column. The species-specific patterns include aspects as; the cyclic abundance of the centric diatom $S$, costatum; the 
episodic blooms of indegenous species that normally do not show bloom in the harbour (C. nana, L. minimus and L. undulatum); the reappearance of endogenous dinoflagellate species that seem to be not recorded during the last decades (G. sanguineum and G. spinifera); and the seasonal shift in predominance and trends (increasingdecreasing abundance and disappearance) of the major dinoflagellate species ( $P$. triestinum, $G$. catenatum and $S$. trochoidea). Although, phytoplankton variability is commonplace from year to another, the quantification of cause, effect and prediction is still problematic.

\section{REFERENCES}

Anderson, D. M. (1997). Bloom dynamics of toxic Alexandrium species in the northeastern. U. S. Limnology and Oceanography, 42: 1009-1022.

Aboul-kassim, T. (1987). Cycles of carbon, nitrogen and phosphorus in the marine environment in Alexandria region. M. Sc., Thesis, Faculty of Science, Alexandria Univ.

Alvarez Cobelas, M.; Velasco, J. L.; Rubio, A. and Rojo, C. (1994). The time course of phytoplankton biomass and related limnological factors in shallow and deep lakes: a multivariate approach. Hydrobiologia, 275-276: 139-151.

Barber, R. T. and Smith, W. O. (1981). Role of circulation in the upwelling center at $15{ }^{\circ} \mathrm{S}$, pp. 366-371. In: Coastal upwelling Ed. by Richards, F. A., Geophys. Union, Washington, D. C.

Cloern, J. E.; and Jassby, A. D. (1995). Year-to-year fluctuation of the spring phytoplankton bloom in South San Francisco Bay: an example for ecological variability at the land-sea interface. In: Ecological Tïme Series, pp. 139-149. Ed. By J. H. Steele, T. M. Powell, and S. Levin. Chapman and Hall, New York.

Cloern, J. E. and Nichols, F. H. (1985). Time scales and mechanisms of estuarine variability, a synthesis from studies of San Francisco Bay. Hydrobiologia, 129: 229-237. 
Colijn, F. (1998). The temporal variability of plankton and their physico-chemical environment. ICES Journal of Marine Science, 55: 557-561.

Demaret, A.; Sohet, K. and Houvenaghel, G. (1995). Effects of toxic dinoflagellates on the feeding and mortality of Artemia franciscana larvae. In: Harmful Marine Algal Blooms. The $6^{\text {th }}$ International Conference on Toxic Marine Phytoplankton, Ed. By Lassus, P, Arzul, G., Erard, E., Gentein, P. and Marcaillou, C. October 1993, Nantes, France, 427-432.

Dodge, J. D. (1982). Marine dinoflagellates of the British Isles. Her Majesty's Stationery Office, London, 303 pp.

Dokulil, M. T. and Padisak, J. (1994). Long-term compositional response of phytoplankton in a shallow, turbid environment, Neusiedlersee. Hydrobiologia, 275-276: 125137.

Dowidar, N. M. (1965). Distribution and ecology of marine plankton in Alexandria and surroundings. Ph. D. Thesis, Univ. of Alexandria, $334 \mathrm{pp}$.

Edmondson, W. T. (1959). Freshwater biology. $2^{\text {nd }}$ ed. John Wiely and Sons. Inc. New York and London. XX, 1248 pp.

El-Nady, F. E. (1981). Survey of some heavy metals in Alexandria waters and its effect on some marine animals. $\mathrm{Ph}$. $\mathrm{D}$. Thesis, Faculty of Science, Alexandria Univ.

El-Maghraby, A. M. and Halim, Y. (1965). A quantitative and qualitative study of the plankton of Alexandria waters. Hydrobiologia, 25 (1-2): 221-238.

Estrada, M.; Sanchez, F. J.; Fraga, S. (1984). Gymnodinium catenatum (Graham) en Las rias gallegas (NO de Espana). Invest. Pesq., 48: 31-40. 
Estrada, M.; Marrase, C. and Alcaraz, M. (1988). Phytoplankton response to intermittent stirring and nutrient addition in marine microcosms. Marine Ecol. Progr. Series 48: 225234.

Falkowski, P. G. and Raven, J. A. (1997). Aquatic photosynthesis, Blackwell Science, 375pp.

Fonda Umani, S.; Sun, C. Y.; Feoli, E.; Cataletto, B.; Cabrini, M. and Milani, L. (1995). Is it possible to identify any plankton succession in the Gulf of Trieste (Northern Adriatic Sea)? In: Biology and Ecology of Shallow Coastal Waters-Proceedings of the $28^{\text {th }}$ European Marine Biology Symp. Pp. 59-65, Ed. By A. Eleftheriou, A. D. Ansell, and C. J. Smith.

Gayoso, A. M. (1998). Long term phytoplankton studies in the Bahia Blanca estuary, Argentina. ICES Journal of Marine Science, 55: 655-660.

Halim, Y. (1960 a). Alexandrium minutum nov. gen. nov.sp. Dinoflagellé Provocant des "eaux rouges". Vie et Milieu, XI: $102-105$.

Halim, Y.; Khalil, A.; and Handhal, Al (1980). Diatoms flora of a eutrophic bay, the Eastern Harbour of Alexandria. Acta Adriatica, 21 (2): 271-298.

Hallegraeff, G. M. (1992). Harmful algal blooms in the Australian region. Marine Pollution Bulletin. 25 (5-8): 186-190.

Hendey, N. I. (1964). An introductory account of the smaller algae of British Coastal Waters, Part 5, Baccilariophyceae. Minist. Agric. Food Invest. Ser., London, Series. 317 pp., 45 pl.

Hintze, J. L. (1993). Number crunched statistical system (NCCS). Version 5 .

Hitchcok, G. L. and Smayda, T. J. (1977). The importance of light of 1972-1973 winter-spring bloom in Narraganstt Bay. Limnology and Oceanography, 22: 126-131. 
Hussein, N. R. (1994). Eutrophication in the Eastern Harbour of Alexandria. M. Sc. Thesis, Faculty of Science, Alexandria Univ.

lizuka, S. (1976). Succession of red tide organism in Omura Bay, with relation to water pollution. Bulletin Plankton Japan, 23: 25-35.

Karentz, D. and Smayda, T. J. (1984). Temperature and seasonal occurrence patterns of 30 dominant phytoplankton species in Narragansett Bay over a 22-year period (1959-1980). Marine Ecology Progress Series, 18: 277-293.

Koray, T. (1992). Noxious Blooms in the Bay of Izmir, Aegean Sea. In: Harmful Algal News, Unesco, IOC (62).

Labib, W. (1992). Amphicrysis compressa Korshikov red tide bloom off Alexandria. Biology of the bloom and associated water chemistry. CERBOM, Centre d'etudes et de recherches de biologie et d'Oceanographie. Tomes, 107-108: 13-23.

Labib, W. (1994a). Ecological study of spring-early summer phytoplankton blooms in a semi-enclosed estuary. Chemistry and Ecology, 9: 75-85.

Labib, W. (1994b). Massive algal pollution in highly eutrophic marine basin, Alexandria, Egypt. The $4^{\text {th }}$ Conf. of the Environ. Prot. is a must, 10-12 May 1994: 181-194.

Labib, W. (1996). Water discoloration in Alexandria, Egypt, April 1993. I- Occurrence of Prorocentrum iriestinum Schiller (Red Tide) bloom and associated physical and chemical conditions. Chemistry and Ecology, 12: 163-170.

Labib, W. (1998). Occurrence of the dinoflagellate Gymnodinium catenatum (Graham) along the Mediterranean coast of Alexandria (Egypt). Chemistry and Ecology, 14: 133-41. 
Labib, W. (2000a). Dinoflagellate "Brown Tides" in Alexandria, Egypt, waters during 1997-1998. Pakistan Journal of Marine Sciences, 9 (1\&2): 33-49.

Labib, W. and Kamel, S. (2000b). Relative importance of the sizefractionated phytoplankton population in temperate waters, Alexandria (Egypt). Egypt. J. Aquat. Biol. \& Fish, 4(1): $47-66$.

Labib, W. and Halim, Y. (1995). Diel vertical migration and toxicity of Alexandrium minutum Halim red tide, in Alexandria, Egypt. Mar. life, 91: 11-17.

Leppänen, J. M.; Kahru, M. and Tulkki, P. (1994a). Monitoring the temporal and spatial distribution of a spring bloom in the eutrophication of the Gulf of Finland. In: Patchiness in the Baltic Sea, pp. 63-68. ICES Comparative researches Rep. No. 201.

Lineboom, H. J.; van Raaphorst, W.; Beukema, J. J.; Cadee, G. C. and Swennen, C. (1995). (Sudden) changes in the North Sea and Wadden Sea: oceanic influences underestimated? Scientific Symposium on the 1993 North Sea quality Status Report, pp. 79-85.

Maita, Y. and Odate, T. (1998). Seasonal changes in sizefractionated primary production and nutrient concentrations in temperate neritic waters of Funka Bay, Japan. Journal Oceanography Socicty Japan, 44: 268-279.

Malej, A.; Mozedic, P.; Turk, V.; Terzić, S.; Ahdel, M. and Cauwet, G. (1998). Effects of nutrients addition on phytoplankton/bacterioplankton interactions and dissolved organic matter variability. Part $\mathbf{1}$. Productivity aspect. In: Ecosystem Research Report, the Adriatic Sea, EU/Environmental Series, Brússels (in press).

Mann, K. H. and Lazier, J. R. N. (1991). Dynamics of marine ecosystems. Biological-physical interaction in the oceans. Blackwell Scientific Publications, Oxford. 466 pp. 
Mihnea, P. E. (1985). Effect of pollution on phytoplankton species. Rapp. Comm. Int. Mer. Medit., $29(9): 85-88$.

Mikhail, S. K. (1997). Ecological Studies of the Phytoplankton Dynamics in Mex Bay. Ph. D. Thesis, Faculty of Science, Alexandria Univ., $266 \mathrm{pp}$.

Mingazzini, M.; Rinaldi, A. and Montanar, G. (1992). Multi-level nutrient enrichment bioassay on Northern Adriatic Coastal waters. Proceeding of the International Conference, Italy, 21-24 March 1990. Marine Coastal Eutrophication, 115131.

Park, J. S. (1991). Red tide occurrence and countermeasure in Korea. In: Recent Approaches on Red Tide, Park, J. S. and Kim, H.G. (eds.). Korean-French Seminar on Red Tides, 9-10 November 1990, Republic of Korea. 1-24 pp.

Park, M. and Dixon, P. S. (1976). Check-list of British marine algae. Third revision, J. Mar. Biol. Ass. U. K., 56: 527-594.

Pybus, C. (1980). Observations on a Gyrodinium aureolum (Dinophyta) bloom off the South Coast of Ireland. Journal Marine Biological Association, United Kingdom. 60 (3): 661-674.

Riegman, R.; Noordelos, A. A. and Cadée, G. C. (1992). Phaeocystis blooms and eutrophication of the continental zones of the North Sea. Marine Biology, 112: 479-484.

Riegman, R. and Kuipers, B. R. (1994). Resource competition and selective grazing of plankton in a multi species pelagic food web mode. P.S.Z.N.I. Marine Ecology, 15: 153-164.

Shriadah, M. (1982). Studies on the chemical composition of the Eastern Harbour. M. Sc. Thesis, Faculty of Science, Alexandria Univ. 
Smayda, T. J. (1980). Phytoplankton species succession. In: The Physiological Ecology of Phytoplankton, pp. 493-570. Ed. By I. Morris. University of California Press, Berkely. 625 pp.

Smayda, T. J. (1983). The phytoplankton of estuaries. In: Estuaries and Enclosed Seas, pp. 65-102,. Ed. By B. H. Ketchum. Elsevier, Amsterdam.

Smayda, T. J. (1990). Novel and nuisance phytoplankton blooms in the sea: evidences for global epidemic, In: Toxic marine phytoplankton, pp. 29-40. Ed. By E. Granéli, B. Sundstrom, L. Edler, and D. M. Anderson. Elsevier, Amsterdam. 554 pp.

Sournia, A. (1986). Atlas du phytoplancton marine. Vol,, I. Cyanophycees, Dictyochophycees, Dinophycees et Raphidophycees. Ed. du CNRS, Paris, 219 pp.

Sournia, A.; Birrien, J.; Douvillé, L.; Klein, B. and Violler, M. (1987). A daily study of the diatom spring bloom at Roscoff (France) in 1985. I. The spring bloom within the annual cycie. Estuarine, Coastal and Shelf Science, 25: 355-367.

Steuer, A. (1935). The fishery grounds near Alexandria. Preliminary Report. Notes and Memories No. 8, Fisheries Research Directorate, Egypt.

Strickland, J. D. and Parsons, T. R. (1972). A practical handbook of sea water analysis $2^{\text {nd }}$ Ed. Bull. Fish. Res. Bd. Can., 167: $310 \mathrm{pp}$.

Sultan, H. A. (1975). Preliminary investigation on the primary production of marine phytoplankton of the Egyptian Mediterranean Coast around Alexandria. M. Sc. Thesis. Alexandria Univ. $151 \mathrm{pp}$.

Thomas, W. H., and Gibson, C. H. (1990). Quantified small-scale turbulence inhibits a re tide dinoflagellate Gonyualax polyedra Stein. Deep-Sea Research, 37: 1583-1593. 
Utermöhl, H. (1958). Zur vervollkommnung der quantitativen phytoplankton-Methodik. Mitt. Int. Ver. Theor. Angew. Limnol., 9: 1-38.

Zaghloul, F. A. (1988). Some physico-chemical indeces of eutrophication in the Eastern Harbour of Alexandria. Bull. Nat. Inst. Oceanogr. \&Fish., ARE, 14(2), 39-53.

Zaghloul, F. A. (1992). Phytoplankton biomass and diversity index in the Western harbour of Alexandria, Egypt. Rapp. Comm. Int. Mer Medit., 33: 268.

Zaghloul, F. A. (1995). Comparative study of phytoplankton production, composition and diversity index in the eutrophic Eastern Harbour of Alexandria, Egypt. Bull. High Inst. Public Health. 25(3): 665-678.

Zaghloul, F. A. and Halim, Y. (1992). Long-term cutrophication in a semi-closed bay: The Eastern Harbour of Alexandria, Science of the Total Environment, Elsevier Science Publisher B.V., Amsterdam, 727-755. 
98

Wagdy Labib

Tn

:

a.

No

a

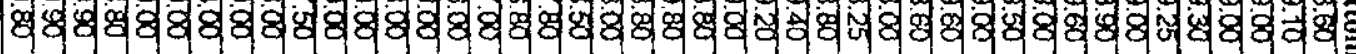

जo

경ํㅕㅇ

ति के क्षे

विज्ञ

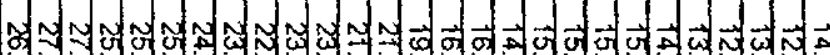

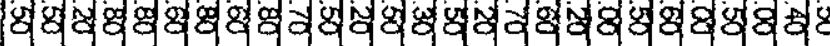

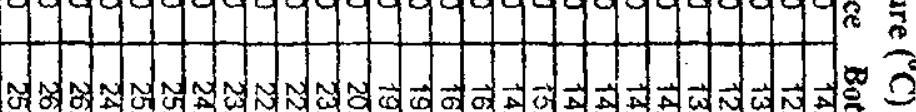

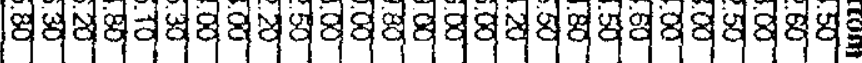

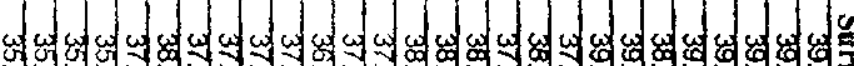

8 영

a.

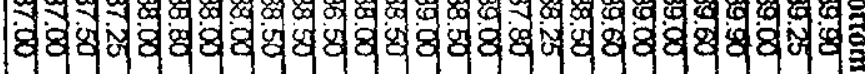

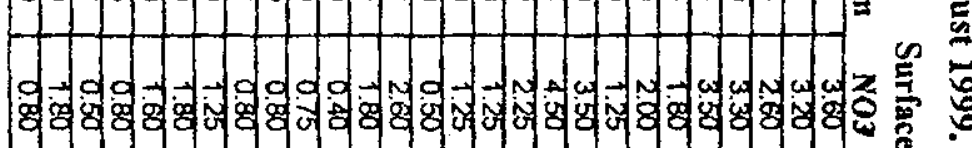

An

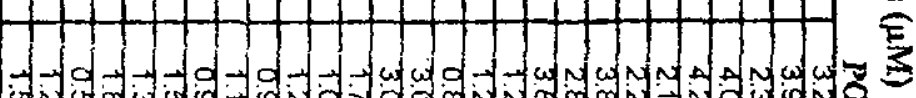

के

:

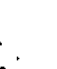




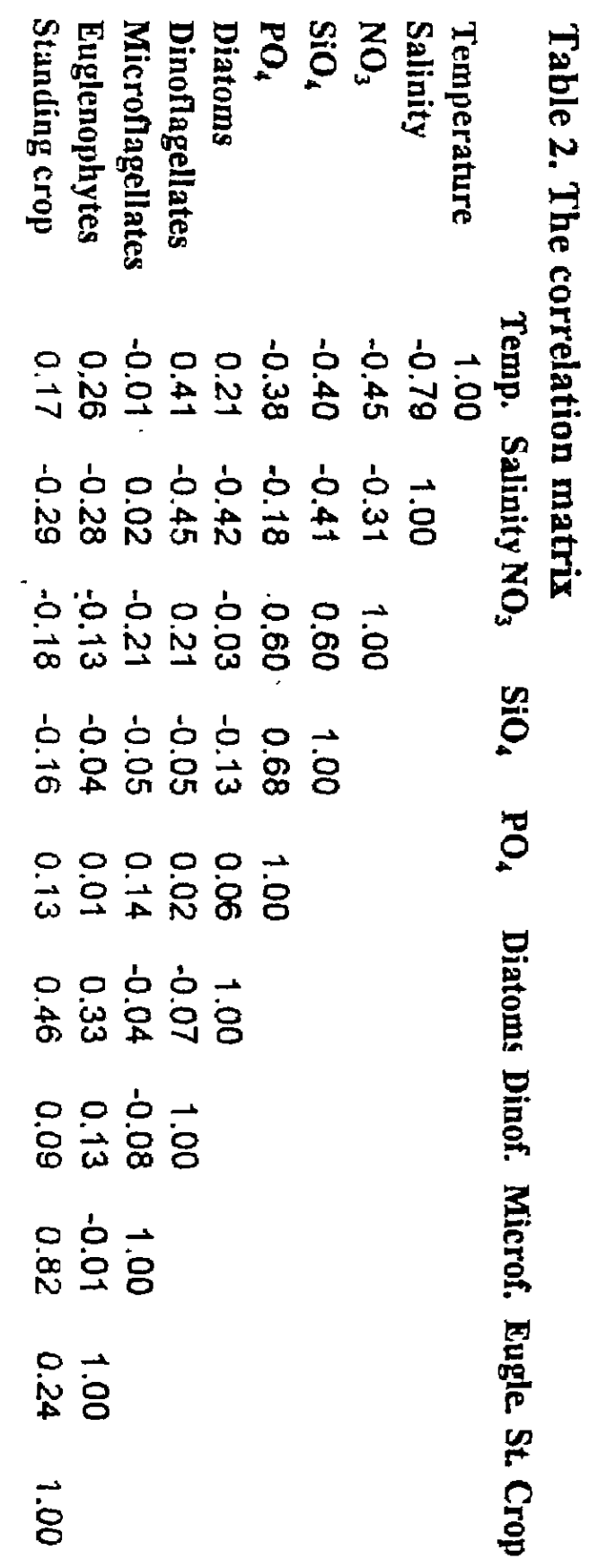




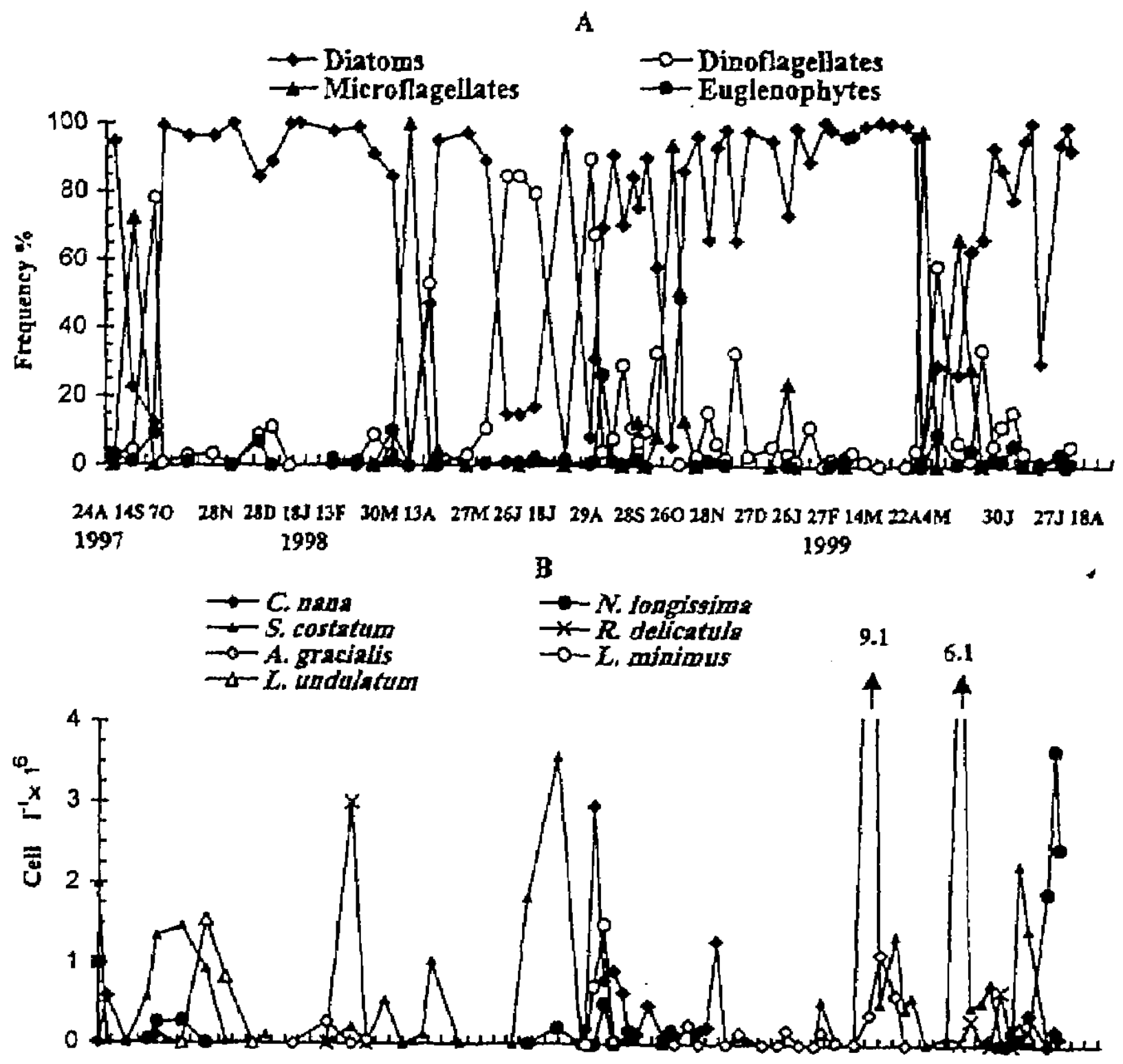

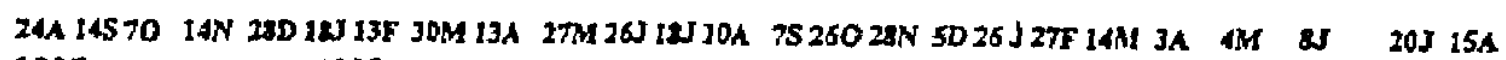
1997 1998 1999

Figure 1. Major phytopingkton groups (A), and the dominant species (B) in the Eastern Barbour. 


\section{PHYTOPLANKTON VARIABILITY IN THE EASTERN 101 HARBOUR ALEXANDRIA (EGYPT)}

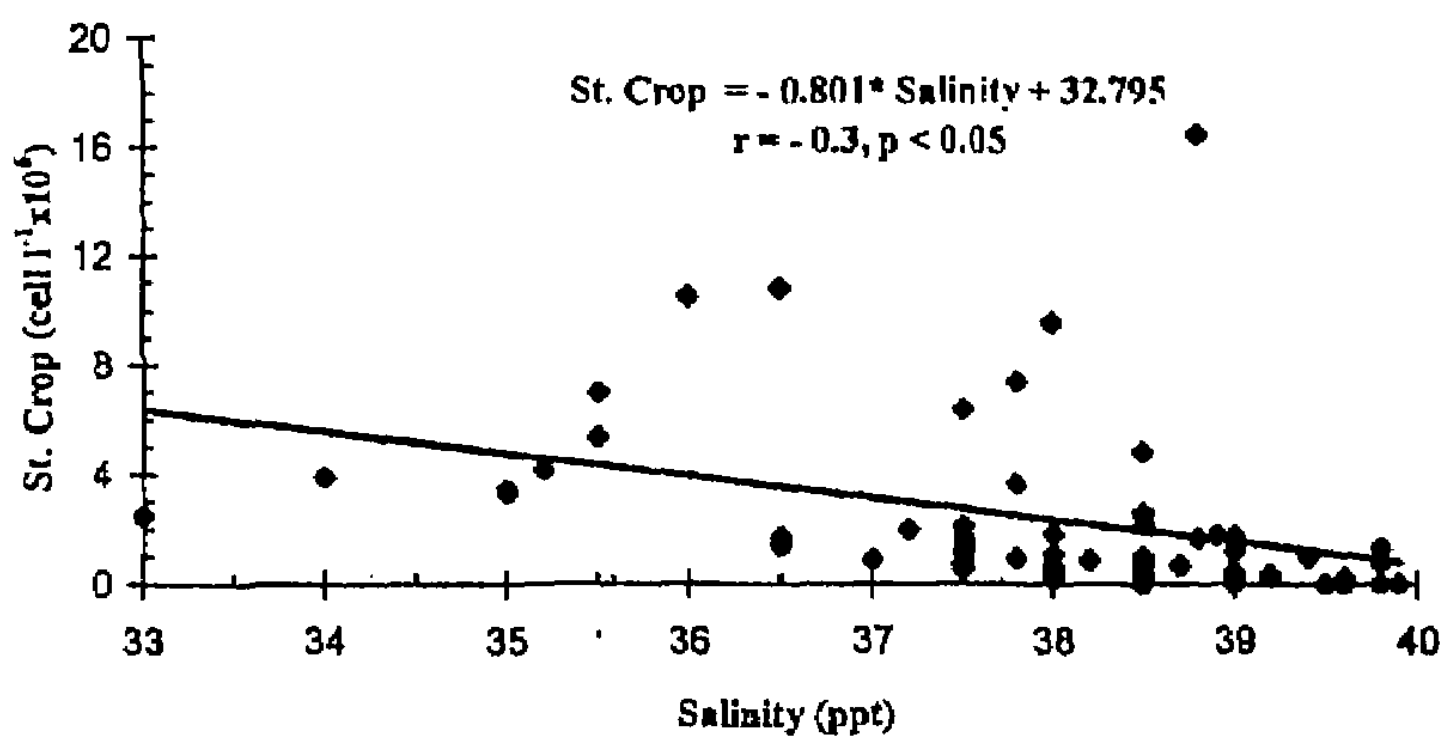

Figure 2. Salinity vs Standing crop

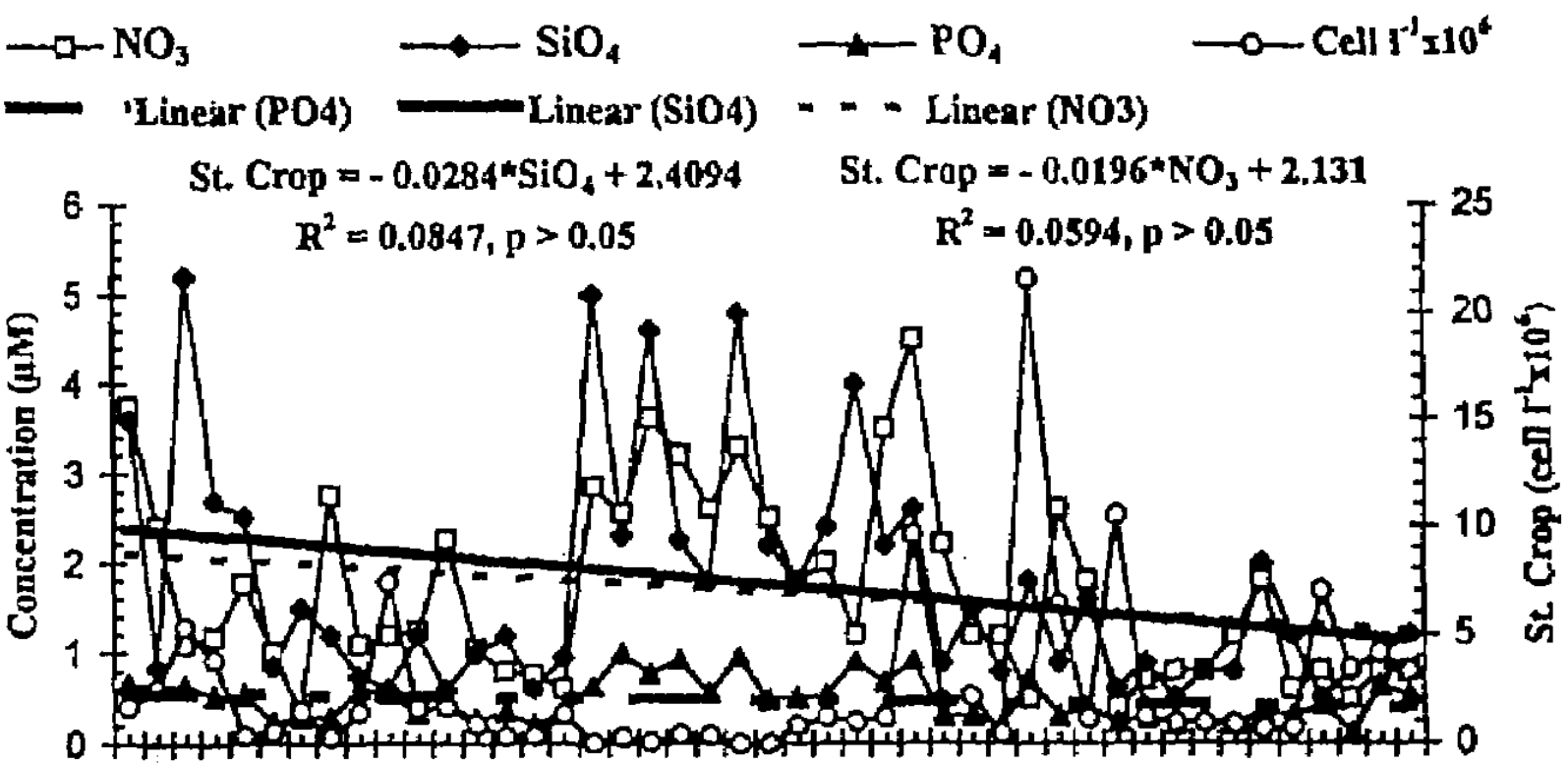

$$
\begin{aligned}
\text { St. Crop } & =-0.016 * \mathrm{PO}_{4}+2.376 \\
\mathrm{R}^{2} & =0.0473, p>0.05
\end{aligned}
$$

Figure 3. Nutrient concentrations vs Stending crop 